\title{
Evaluation of New Trials in Controlling Two Olive Lepidopteran Insect-Pests of Olive Trees, in Egypt

\author{
Hassan. A. Mesbah ${ }^{1}$, El-Sayed H.Tayeb ${ }^{1}$ and Zaki. M. Atia ${ }^{2}$
}

\begin{abstract}
Field experiments evaluation were carried out in a private orchard cultivated with olive trees of (Manzanillo cultivar) at Wady El-Natroon region, throughout two subsequent seasons of 2016 and 2017 to control both of the lepidopteran olive moths; Prays oleae and the jasmine moth, Margaronia unionlis. Five treatments was applied; the release of the parasitoid-Trichogramma evanescens alone or followed with certain insecticides.

The results showed that the subsequent monthly use treatment of release the parasitoid- $T$. evanescens then Nimbecidine $^{\circledR} 0.03 \%$ E.C against $P$. oleae gave the best efficient treatment recording higher infestation reductions of 83.41 and $82.12 \%$ in both seasons of 2016 and 2017, respectively, followed by the more or less efficiency bimonthly release of the $T$. evanescens then Nimbecidine ${ }^{\circledR}$ 0.03\% E.C, Nimbecidine ${ }^{\circledR}$ 0.03\% E.C, Deltachem Super ${ }^{\circledR}$ $2.6 \%$ E.C, and release of $T$. evanescens only, that gave $60.11 \& 67.88 \%, 57.85 \& 64.63 \%, 55.16 \& 56.91 \%$ and $52.48 \& 53.66 \%$, respectively.
\end{abstract}

As for the M. unionlis the results indicated that the subsequent monthly use treatment of release the $T$. evanescens then Nimbecidine ${ }^{\circledR} 0.03 \%$ E.C gave the best efficient control recording higher infestation reductions of 86.89 \& $80.39 \%$ in both seasons 2016-2017, respectively, followed by the performed treatment of Nimbecidine ${ }^{\circledR}$ $0.03 \%$ E.C, the bimonthly release of $T$. evanescens then Nimbecidine $^{\circledR}$ 0.03\% E.C, Deltachem Super $^{\circledR} 2.6 \%$ E.C, and release of $T$. evanescens only, that gave infestation reductions amounted to $77.75 \& 68.81 \%, 70.73 \& 64.31 \%$, $70.43 \& 63.99$ and $60.37 \& 52.09 \%$, respectively.

Therefore, the monthly hang of the cards of parasitoidT. evanescens followed by Nimbecidine ${ }^{\circledR} 0.03 \% \quad$ E.C application at the following month could be recommended as effective of control both the insect-pests.

Key words: controlling; olive lepidopteran; insect-pests; olive trees, Egypt.

\section{INTRODUCTION}

Olive (Olea europaea L.) has become one of the important economic horticultural crops in the world especially Egypt. Its cultivated area reached 227683 feddans with production-698927 tons in 2015 (MALR, 2016). Olive trees are infested by certain lepidopteran pests, in particular the olive moth, Prays oleae (Bern.) and jasmine moth, Palpita unionalis (Huebner), which cause direct yield loss in olive orchards (Herz et al., 2005 ). They are the most important lepidopteran insect- pests of olive in the Mediterranean basin (LopezVillata, 1999). The damage caused by olive moth, $P$. oleae reduced production from 50 to $60 \%$ in modern cultivars (Ramos et al., 1998 and Patanita and Mexia, 2004). The jasmine moth, Palpita unionalis (Huebner) is present throughout the Mediterranean region, Asia Minor, and North Africa (Kovanci and Kumral, 2008). These insect pests attack olive leaves, flower buds and olive fruits, making them unacceptable to the commercial market (Balashowsky, 1972; Foda, 1973; El-Kifl et al., 1974 and El-Sherif, 1975).

Problems associated with insecticide spraying such as resistance, adverse effect on beneficial insects, environmental pollution and costs, have cast doubt on the viability of the long-term synthetic insecticide approach to control these pests (Yousef et al. 2004). In many situations, economically acceptable low levels of caterpillars infestations can be maintained by use of alternative methods of control, such as the use of biological agents. Trichogramma species are the most widely used as an insect natural enemy ( $\mathrm{Li}, 1994)$, particularly because they are easy to mass rear and they attack many important crop insect pests. The species of Trichogramma attacks more than 400 insect-species pertaining for 203 genus, 44 families and seven orders (Bao and Chen, 1989).

Therefore, the objectives of the present study were conducted:

(a) evaluate the effectiveness of $T$. evanescens release upon the olive moth, Prays oleae and the jasmine moth, Margaronia unionlis.

(b) comparison between the efficiency of periodical parasite release with the application of Nimbecidine ${ }^{\circledR} 0.03 \%$ E.C.

(c) determine the most profitable consequence of parasite release and chemical treatment.

\section{MATERIALS AND METHODS}

\section{Field experiments}

The experiments were carried out at private orchard in Wady El-Natroon region, beside El-Dawly ElAlamein road, $90 \mathrm{Km}$ South West of Alexandria Governorate, Egypt, cultivated with olive trees, during the following successive seasons of 2016 and 2017 to control the common prevailing lepidopteran insect-pests

${ }^{1}$ Plant Protection Dept., Faculty of Agric. (Saba Basha), Alex. Univ., Egypt.

${ }^{2}$ Plant Protection Dept., Faculty of Agric., Tripoli Univ., Libya.

Received April 10, 2018, Accepted May08, 2018 
of olive trees. The selected area for adopted experiment was divided into many longitudinal blocks by spacing $606 \mathrm{~m}^{2}$. The growing olive trees species were alternatively and randomly apart from each other all over the different chosen blocks. The mainly inspected blocks were cultivated with Manzanillo olive trees. Treatments were arranged in a complete randomized block design with three replicates for each treatment plus three replicates as check during the consequent seasons of study.

In the subsequent seasons of 2016 and 2017, the initiated five treatments plus the untreated check were performed in three randomly selected blocks for the run study. each of these blocks implied three rows of growing olive trees, from which three trees were randomly chosen for each of the run treatments. Though, each of the performed treatment was thricely replicated, and each replicate contained three olive trees.

\section{The insects subjected to study}

Two lepidopteran insect-pests were commonly found infesting the olive trees of Manzanillo cultivar, namely the olive moth, Prays oleae and the jasmine moth, Margaronia unionlis.

Parsitoid of Trichogramma evanescens: The commercially available species $T$. evanescens Westwood for use in crops, vegetables and fruits was attained from the Laboratory of Agriculture Faculty, Cairo University. Releasing cards were prepared by gluing approximately 500 parasitized eggs of the lepidopteran moth Ephestia kuehniella by $T$. evanescens.

${\text { Azadirachtin } \quad \text { (Nimbecidine }^{\circledR} \quad \mathbf{0 . 0 3 \%}}^{\text {E.C): }} \quad$ The principal insecticidal ingredient of neem seed extracts (Extracted from the neem tree, Azadirachta indica).

Application rate: $5 \mathrm{cc} / 1$ liter water

Deltamethrin: A synthetic pyrethroid (Deltachem Super $^{\circledR} 2.6 \%$ E.C).

Application rate: $900 \mathrm{cc} /$ Feddan

Treatments

The five adopted treatments were tested:

\section{Parasitoid of Trichogramma evanescens}

The monthly used cards of $T$. evanescens were hang (one card per tree) at a height of $1.5 \mathrm{~m}$ from the surface of the soil and a distance of $15-20 \mathrm{~cm}$ inside the tree.

2. Alternative monthly treatment of Parasitoid of $\boldsymbol{T}$. evanescens then Nimbecidine ${ }^{\circledR} 0.03 \%$ E.C

The olive trees were monthly sprayed with Nimbecidine ${ }^{\circledR} 0.03 \%$ E.C alternatively with the hang of the parasitoid cards in the following month, during the consequent growing seasons of 2016 and 2017.

\section{Alternative bimonthly treatment of Parasitoid of} T. evanescens then Nimbecidine ${ }^{\circledR} 0.03 \%$ E.C

The olive trees were alternatively sprayed each two months with Nimbecidine ${ }^{\circledR} 0.03 \%$ E.C with a sequent use of $T$. evanescens cards for the same period during the following growing seasons of 2016 and 2017.

4. Parasitoid of $T$. evanescens then Synthesized insecticide (Deltachem Super ${ }^{\circledR}$ 2.6\% E.C)

In this experiment the olive trees only were sprayed with Deltachem Super ${ }^{\circledR} 2.6 \%$ E.C for one time, on April, the $6^{\text {th }}$, in addition of the use T. evanescens cards for one time on June, the $11^{\text {th }}$ during the following growing seasons of 2016 and 2017.

\section{Botanical insecticide (Nimbecidine ${ }^{\circledR}$ 0.03\% E.C) only}

The olive trees were bimonthly sprayed with Nimbecidine ${ }^{\circledR} 0.03 \%$ E.C during the growing season of 2016 and 2017.

\section{Sampling technique}

Forty branches from each treated tree were randomly sampled from the four cardinal directions of tree (east, west, north and south), i.e. Ten branches from each tree direction were separately collected and inspected for counting the existing larvae of the insect pest. The counted numbers of larvae on the infested branches during the period of study (March up to the end of September) were recorded in each of the preformed treatments plus check.

The infestation percentages were fortnightly calculated along the elapsed interval of the done treatment.

\section{Calculation of the infestation reduction}

The infestation of both insects was investigated pre treatment application and after 15 days from treatment performance, the mean reduction percentages were calculated according to the equation of Pandey et al. (1982) as follows:

$$
\text { Reduction } \%=\frac{\text { Control }- \text { Treatment }}{\text { Control }} \times 100
$$

\section{Statistical analysis}

All collected data were subjected to analysis of variance according to Gomez and Gomez (1984). All statistical analysis was performed using analysis of variance technique using CoStat computer software package (CoStat, Ver. 6.311., 2005). The least significant difference (LSD at 0.05) was used to compare the treatment means. 


\section{RERSULTS AND DISCUSSION}

\section{Efficacy of adopted treatments against $P$. oleae}

Results of the first season of 2016 are presented and illustrated in Table (1). The data showed that the highest of reduction percentages of $83.41 \%$ was detected for the treatment of monthly release of the $T$. evanescens then Nimbecidine ${ }^{\circledR} 0.03 \%$ E.C followed by the less higher $60.11 \%$ percentage of the bimonthly performed treatments of the $T$. evanescens then Nimbecidine ${ }^{\circledR}$ $0.03 \%$ E.C. In the same time, the least effective treatment were corresponded to the lonely used Nimbecidine $^{\circledR} 0.03 \%$ E.C-57.85\%, Deltachem Super ${ }^{\circledR}$ $2.6 \%$ E.C-55.16\% and T. evanescens parasitoid-52.48\% reductions, successively.(Table 1 ).

Perusing carefully at the results during the second season of 2017, The repeatedly performed treatments of monthly and/or bimonthly use of the parasitoid- $T$. evanescens then Nimbecidine $囚 0.03 \%$ E.C, came at the top of assigned treatments, and recorded reduction percentages of $82.12 \%$ and $67.88 \%$, followed by the less efficient treatments of Nimbecidine ${ }^{\circledR} 0.03 \%$ E.C, Deltachem Super $2.6 \%$ E.C and T. evanescens parasitoid with reduction percentages of $64.63,56.91$ and $53.66 \%$, successively. (Table 2).

\section{Efficacy of performed treatments against $M$. unionalis}

The obtained results of the first season of 2016 are presented and illustrated in Table (3). The data indicated that the highest reduction percentages of $86.89 \%$ and $77.75 \%$ were attained for the consequent treatments of monthly release of the parasitoid- $T$. evanescens then Nimbecidine ${ }^{\circledR} 0.03 \%$ E.C, and Nimbecidine $^{\circledR} 0.03 \%$ E.C, done successively. On the other hand, the less effective ones corresponded to the bimonthly release parasitoid- $T$. evanescens then Nimbecidine ${ }^{\circledR} 0.03 \%$ E.C-70.73\%, Deltachem Super ${ }^{\circledR}$ $2.6 \%$ E.C-70.43\% and T. evanescens parasitoid-60.37\% reductions, successively, as shown in (Table 3).

However, in the second season of 2017, data showed that the treatments of the monthly release parasitoid- T. evanescens then Nimbecidine ${ }^{\circledR} 0.03 \%$ E.C and Nimbecidine ${ }^{\circledR} 0.03 \%$ E.C alone came at the top of assigned treatments, in recording reduction percentages of $80.39 \%$ and $68.81 \%$, in respect, followed by the comparatively less effective treatments of Deltachem Super $^{\circledR} 2.6 \%$ E.C, bimonthly release of the parasitoid$T$. evanescens then Nimbecidine ${ }^{\circledR} 0.03 \%$ E.C and the alone release of $T$. evanescens parasitoid with reduction percentages of $63.99,64.31$ and $52.09 \%$, respectively. (Table 4).

From the above cited results it could be revealed that the utmost efficient treatment against both of the inspected lepidopteran insect-pests of olive trees is the monthly release of $T$. evanescens parasitoid cards followed by a following spray of Nimbecidine ${ }^{\circledR} 0.03 \%$ E.C and to attain highest reduction percentage of both occurring insect-pests.

The above demonstrated results were in agreement with those mentioned by earlier investigators for example, Fodale et al. (1990) found that spray of $0.03 \%$ methidathion, $0.14 \%$ fenthion, $0.06 \%$ dimethoate, $0.09 \%$ carbaryl and $0.006 \%$ Bacillus thuringiensis against $P$. unionalis gave good control at the beginning of infestation when larvae were in the $1^{\text {st }}$ and $2^{\text {nd }}$ instar. On the other hand, Ruiz and Bueno (2009) showed the impacts of pyrethroids (deltamethrin, lambdacyhalothrin and alpha -cypermethrin) on the arthropod communities of olive orchards. Treatments against $P$. oleae were applied in one homogeneous olive orchard in Jaen province. The alpha -cypermethrin treatment significantly decreased the arthropod population. In the deltamethrin treatment, captures were decreased at the third week. The lambda -cyhalothrin treatment also had more significant differences in the predatory arthropod populations and the deltamethrin treatment on the parasitic populations. Torres and Bueno (2009) determined the impacts of pyrethroids (deltamethrin, lambda -cyhalothrin and alpha -cypermethrin) on the arthropod communities of olive orchards. alpha cypermethrin treatment significantly decreased the arthropod population. In the deltamethrin treatment, captures were decreased at the third week. The lambdacyhalothrin treatment also had more significant differences in the predatory arthropod populations and the deltamethrin treatment on the parasitic populations . These results implied \% reduction of the pests, which may have reflection on yield of olive. 


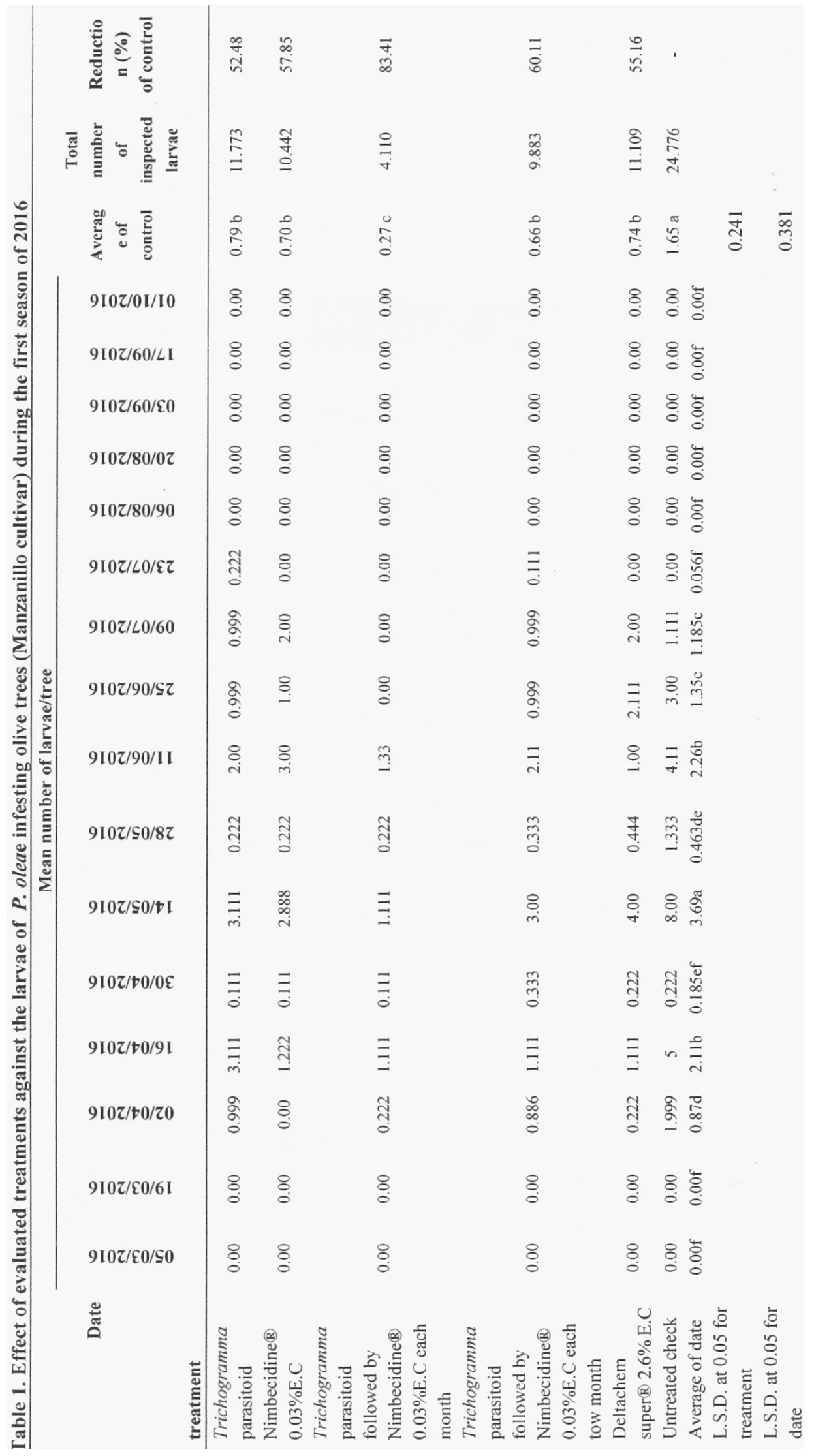




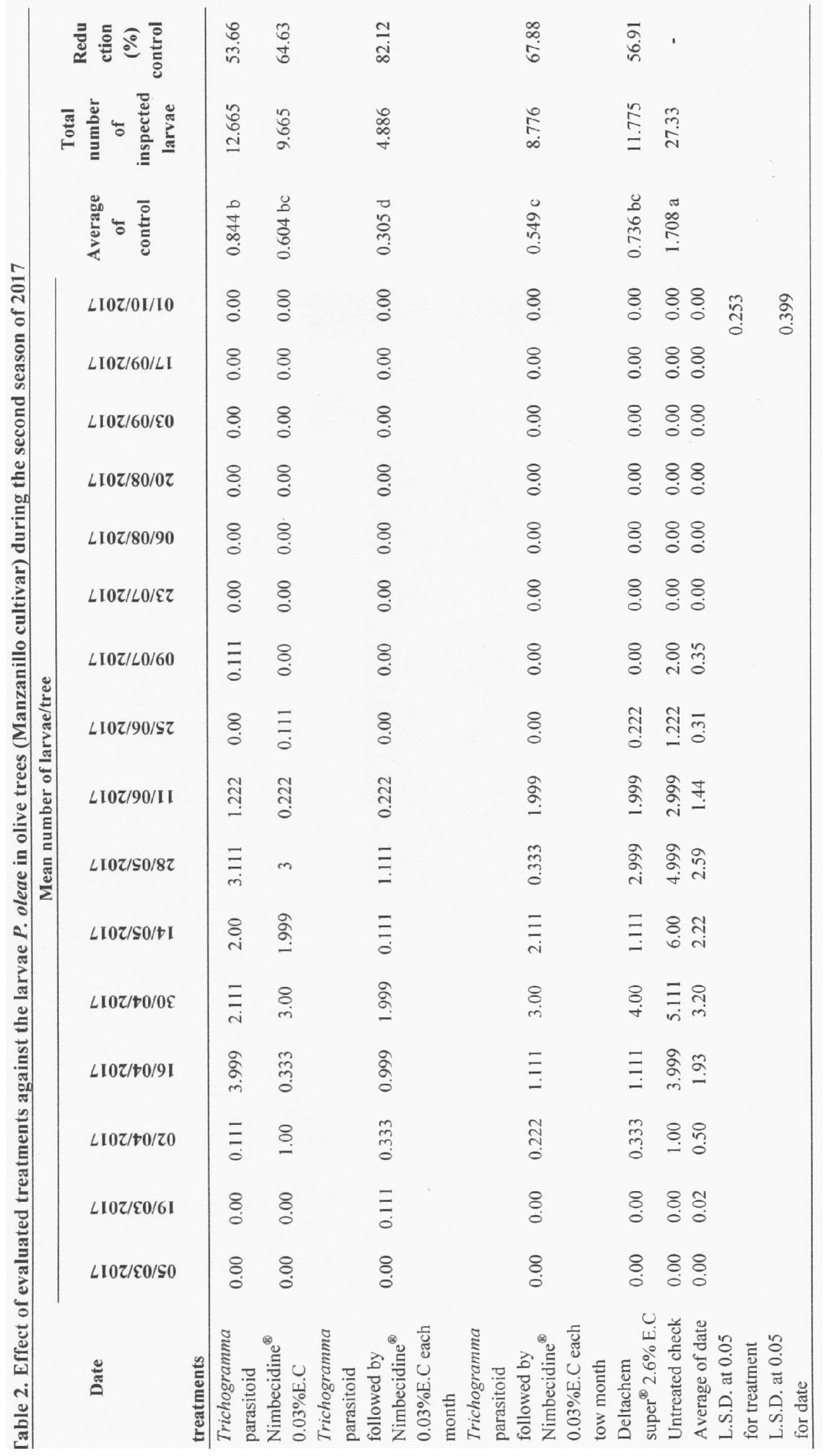




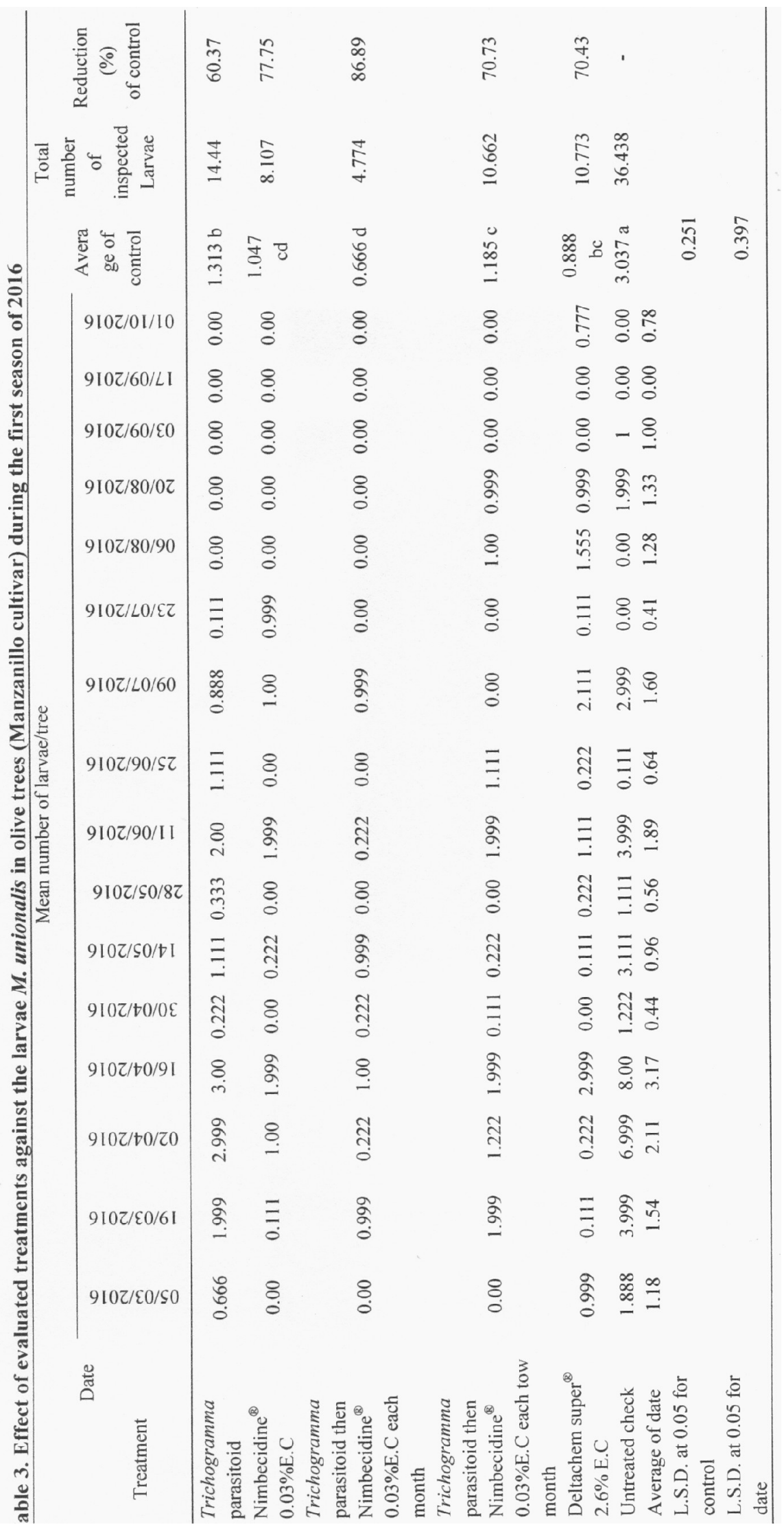




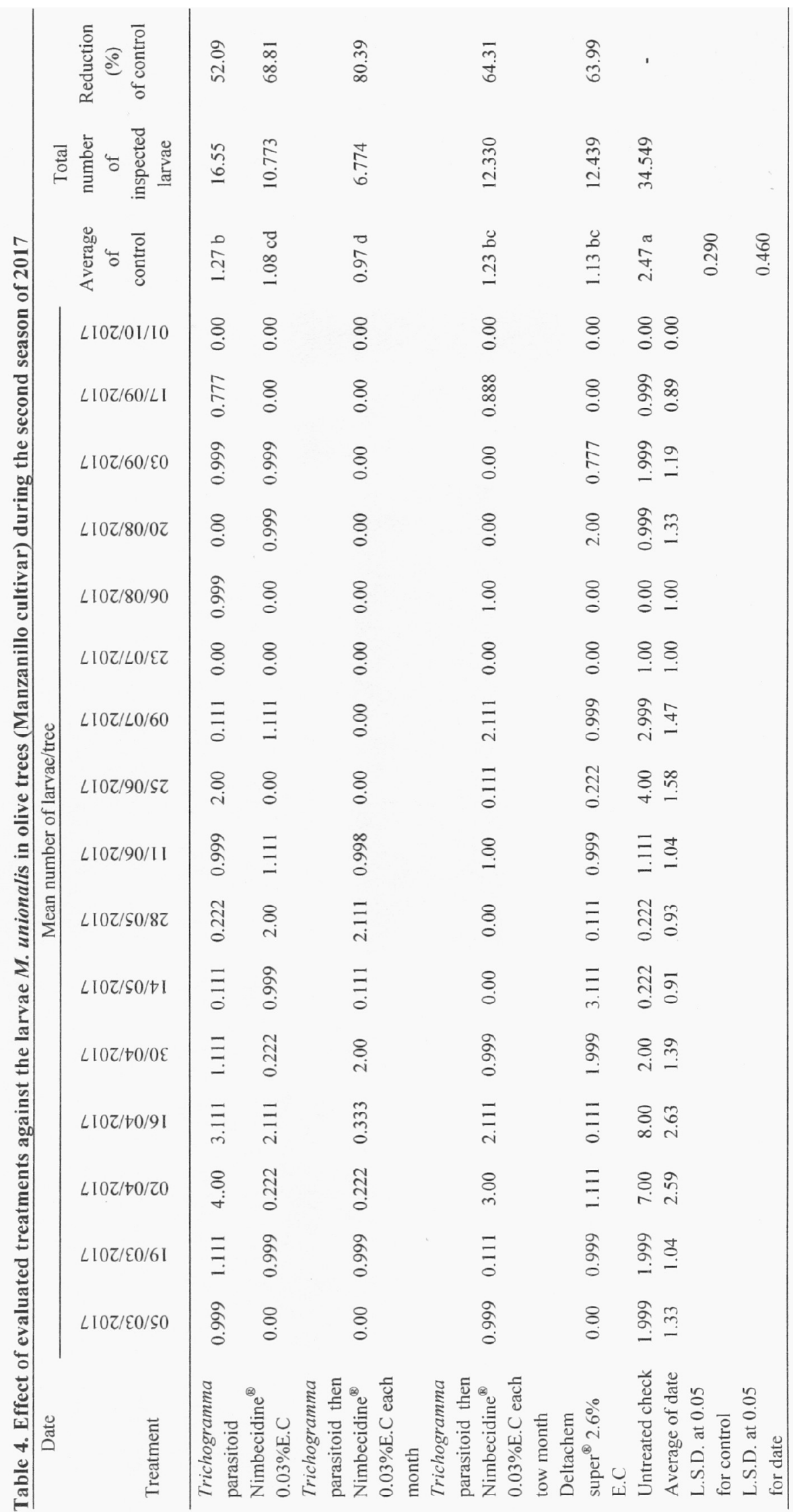




\section{REFERENCES}

Balashowsky, A. S. 1972. Entomologie Appliquuee a 1'Agriculuree. Vol. 1, Lepidopteres, Masson, Paris. pp 1131-1133.

Bao, J. Z. and X. H. Chen. 1989. Research and application of Tricogramma in China, Academia Books and periodicals Scienc Press, Beijing. 220p.

CoStat Ver. 6.311. 2005. Cohort software798 light house Ave. PMB320, Monterey, CA93940, and USA. email: info@cohort.com and Website: hittp://www.cohort.com/DownloadCoStatPart2.html

El-Kifi, A. H., A. L. Abdel-Salam and A. M. M. Rahhal. 1974. Biological studies on the olive leaf-moth, Palpita unionalis $\mathrm{Hb}$. (Lepidoptera: Pyralidae). Bulletin of Entomological Society of Egypt. 58: 337-344.

El-Sherif, L. S. 1975. Biological and ecological studies on the Jasminium moth, Palpita unionalis Hb., and the olive moth, Zelleria oleastrella Mill. phD thesis, Faculty of Science, Ain Shams University, Egypt.

Foda, S. M. A. 1973. Studies on Margaronia (Glyphodes) unionalis and its control. M. Sc. Thesis, Faculty of Agriculture, Ain Shams University, Egypt.

Fodale, A. S., R. Mule and A. Tucci. 1990. Bioethological observations on Margaronia unionalis $\mathrm{Hb}$, in Sicily and trials on its control. [Italian]. Annali dell'Istituto Sperimentale per l'Olivicoltura, publ. 10:31-44.

Gomez, A. K. and A. A. Gomez. 1984. Statistical procedures for agricultural research. ( $2^{\text {nd }}$ edition). John Wiley and Sons. New York.

Herz, A., S. A. Hassan, E. Hegazi, F. N. Nasr, A. A. Youssef, W. E. Khafagi, E. Agamy, K. Mohieddine, J. Taieb, B. E. Mazomenos, M. A. Konstantopoulou, L. Torres, F. Goncalves, A. Bento and J. A. Pereira. 2005. Towards sustainable control of Lepidopterous pests in olive cultivation. Gesunde Pflanzen. 57(5): 117-128.

Kovanci, B. and N. A. Kumral. 2008. Insect pests in olive groves of Bursa (Turkey). Acta Horticultura. 791: 569576.
Li, L. Y. 1994. World-wide use of Tricogramma for biological control on different crops; a survey. pp 37-54. In: Biological with egg parasitoids. E. wajnberg and S. A. Hassan [eds.], CAB, Wallingfork, UK.

Lopez-Vallita, M. C. 1999. Olive pest and disease managament. International Olive Oil Control, Principe de Vergana. 154-282002. Madrid. 206p.

MALR. 2016. Bulletin of the Agriculture Statistics. Summer and Nili Crops, 2014/2015. Ministry of Agriculture and Land Reclamtion, Egypt. Part. (2): 337-338.

Pandey, D. K, N. N. Tripathi, R. D.Tripathi and S. N. Dixit. 1982. Fungi toxic and phytotoxic properties of essential oil of Hyptis suaveolens. Z. Pfl. Kramkh. Fl. Schutz. 89(6): 344-349.

Patanita M. I. and A. Mexia. 2004. Loss assessment due to Prays oleae Bern. and Bactrocera oleae Gmelin in Moura's region (Portugal) (www document). (http://publo.ipbeja.pt/Artigos/Italia.httm).

Ramos, P., M. Campos and J. M. Ramos. 1998 . Long-term study on the evaluation of yield and economic losses caused by Prays oleae Bern. in the olive crop of Granada (southern Spain). Crop Protec. 17(8): 645-647.

Ruiz, T. M. and A. M. Bueno. 2009. Effects of pyrethoroids treatments on arthropods communities in olive grove of Jaen province (Spain). Boletin de Sanidad Vegetal, Plagas. 35(1): 147-169.

Torres, R. M. and A. M. Bueno. 2009. Effects of pirethoroids treatments on arthropods communities in olive grove of Jaen province (Spain). Boletin de Sanidad Vegetal, Plagas. 35(1): 147-169.

Youssef, A. A., F. N. Nasr, S. S. Stefanos, S. S. Abou Elkhair, W. A. Shehata, E. Agamy, A. Herz and S. A. Hassan. 2004. The side effects of plant protection products used in olive cultivation on the hymenopterous egg parasitoid Trichogramma cacoeciae Marchal. Journal of Applied Entomolog. 128: 593-599. 


\title{
الملخص العربي
}

\section{تقييم معاملات جديدة لمكافحة آفتين حشريتين من حرشفية الأجنحة التي تصيب أشجار الزيتون في}

\author{
مصر \\ حسن على عبد الحميد مصباح ، السيد حسن محمد تايب و ز اكي محمد على عطية
}

أما بالنسبة لحسـشرة دودة أوراق الزيتــون الخــضراء

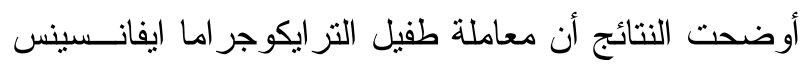

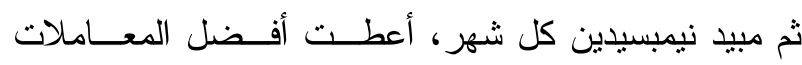

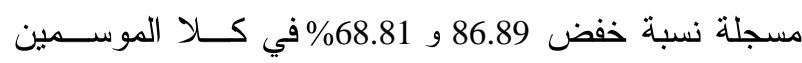

2017 و 2016 على التزتيب، يليها المعاملة بمبيد النيمبسيدين

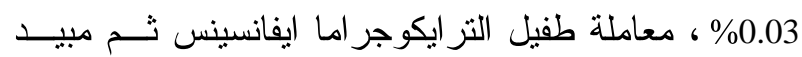

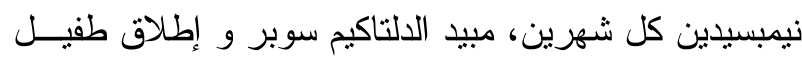

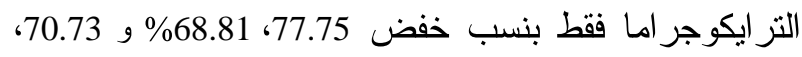
64.31\% و 70.43، 63.99 و 60.37، 52.09\% على الترتيــب،

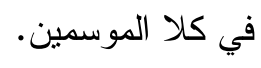

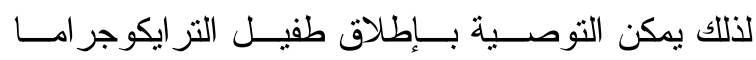

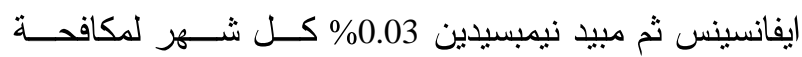

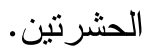

أجريت تجربتين حقليتين في مزرعة خاصة منزرعـة

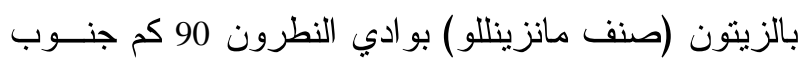
غرب مدينة الإسكندرية بجانب الطريق الدولي لمدة موسمين متتاليين 2016 و 2017 لمكافحة دودة ثمار الزيتــون ودودة أوراق الزيتون الخضر اء، بتطبيق بعض المواد الكيميائيــة مع إطلاق طفيل التر ايكوجر اما ايفانسينس.

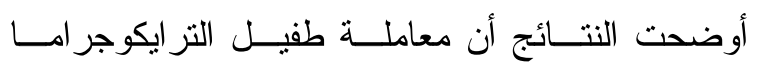

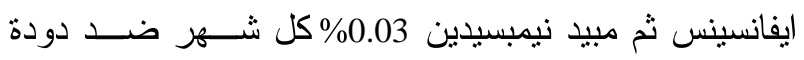
ثمار الزيتون كأفضل مكافحة فعالة حيث سجلت أعلى نسبة ثئية

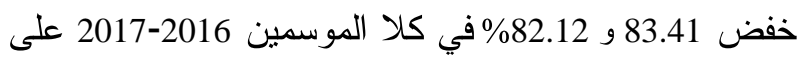
الترتيب، يليها معاملة طفيل التر ايكوجر اما ايفانسينس ثم مبيد

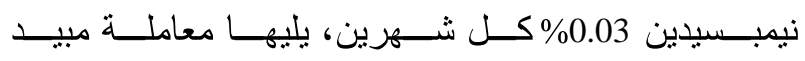

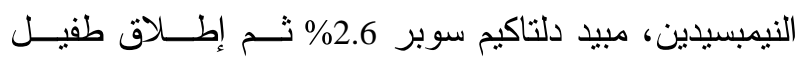

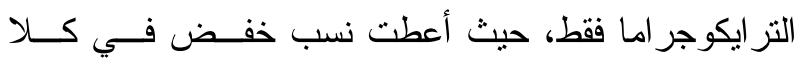
الموســين 60.11 ، 67.88 \% و 57.85 ، 64.63\% و 55.91 و 56.90 على الترتيب. 